\title{
一种新型用于 $\mathrm{CN}^{-}$比色检测和 $\mathrm{Zn}^{2+} / \mathrm{H}_{2} \mathrm{PO}_{4}^{-}$荧光识别的二芳烯探针
}

\author{
丁璐王仁杰* 王念省 刘 刚蒲守智* \\ (江西科技师范大学有机功能分子重点实验室 南昌 330013)
}

\begin{abstract}
摘要 合成了一种新型二芳烯 1-(3,5-二甲基异噁唑-4-基)-2-\{2-甲基-5-[(3-亚氨基萗酚-2-基)苯酚基]-噻吩-3-基 $\}$ 全氟环 戊烯 $(10)$ 双重响应化学传感器, 系统地研究了在光和离子刺激下 10 的光致变色和荧光开关性质. 实验结果表明, 10 能 够对 $\mathrm{CN}^{-} / \mathrm{F}^{-}$裸眼识别, 在 $\mathrm{CN}^{-} / \mathrm{F}^{-}$作用下溶液的颜色从无色逐渐变为黄色; 同时, 10 可作为 “Turn-on” 型苂光探针对 $\mathrm{Zn}^{2+}$ 进行专一性识别. 10 对 $\mathrm{CN}^{-}$和 $\mathrm{Zn}^{2+}$ 的检测极限分别达到 $1.03 \times 10^{-6}$ 和 $2.98 \times 10^{-8} \mathrm{~mol} \cdot \mathrm{L}^{-1}$. 关键词 二芳烯; 化学传感器; 锌离子; 氧根离子; 苂光增强
\end{abstract}

\section{A New Diarylethene Probe for Colorimetric Detection of $\mathrm{CN}^{-}$and Fluorescent Recognition of $\mathrm{Zn}^{2+} / \mathrm{H}_{2} \mathrm{PO}_{4}^{-}$}

\author{
Diao, Lu Wang, Renjie* Wang, Niansheng Liu, Gang $\quad \mathrm{Pu}$, Shouzhi* \\ (Jiangxi Key Laboratory of Organic Chemistry, Jiangxi Science and Technology Normal University, Nanchang 330013)
}

\begin{abstract}
A new diarylethene 1-(3,5-dimethylisoxazole-4-yl)-2-(2-methyl-5-[(3-aminonaphthol-2-yl)phenol-yl]-thiophene-3yl)perfluorocyclopentene (10) dual-response chemosensor has been synthesized, and its photochromic and fluorescent switch behaviors were systematically investigated by stimulation of lights and ions. The results indicated that $\mathbf{1 0}$ could serve as a $\mathrm{CN}^{-} / \mathrm{F}^{-}$"naked-eyes" colorimetric sensor with the color change from colorless to yellow, and act as a "Turn-on" fluorescence probe for specific detecting $\mathrm{Zn}^{2+}$. Moreover, the limits of detection of $\mathrm{CN}^{-}$and $\mathrm{Zn}^{2+}$ were determined to be $1.03 \times 10^{-6}$ and $2.98 \times 10^{-8} \mathrm{~mol} \cdot \mathrm{L}^{-1}$, respectively.

Keywords diarylethene; chemosensor; $\mathrm{Zn}^{2+} ; \mathrm{CN}^{-}$; fluorescence enhancement
\end{abstract}

\section{Introduction}

Cations and anions have series important meanings in biological processes. ${ }^{[1]}$ Among those ions, $\mathrm{Zn}^{2+}$ is one of the most abundant transitional elements, in the terms of biological processes, such as enzyme regulation, brain function, protein synthesis, DNA (deoxyribonucleic acid) repair and neurotransmission. ${ }^{[2]}$ Those evidences exhibited that $\mathrm{Zn}^{2+}$ is related to a various of neurological diseases, such as Alzheimer's diseases, amyotrophic lateral sclerosis, hypoxia-ischemia and epilepsy. ${ }^{[3]}$ According to the WHO (World Health Organization) data displayed, more than $40 \%$ children in Africa and Asia were caused harmful problems because of the limited uptake of $\mathrm{Zn}^{2+} \cdot{ }^{[4]}$ Meanwhile, a large amount of $\mathrm{Zn}^{2+}$ can lead to phytotoxic effects on soil microbes. ${ }^{[5]}$ Therefore, it is highly desirable to develop sensitive and selective sensor to detect $\mathrm{Zn}^{2+}$ in the environment, living cells, and tissues. Similarly, phosphate and cyanide anions are required to avoid excessive presence in biological processes generated by stoichiometric imbalance in living systems. Cyanide is highly toxic and it has significant lethality when it is exposed to the organism and the environment, such as causing vomiting, convulsion, thus causing dyspnea and even death. ${ }^{[6]}$ However, this does not hinder its application in metallurgy, plastic processing, petrochemical, photographic, resins and herbicides. ${ }^{[7]} \mathrm{H}_{2} \mathrm{PO}_{4}^{-}$plays an important role in metabolic process, energy storage and construction of the backbone of DNA and RNA (ribonucleic acid). ${ }^{[8]}$ Some common diseases, including hyperthyroidism, kidney failure, bone disorders, and hypertension are caused by excessive phosphates. ${ }^{[9]}$ As a result, highly sensitive and selective sensors

\footnotetext{
* Corresponding authors. E-mail: bio-wri@163.com; pushouzhi@tsinghua.org.cn

Received January 24, 2019; revised March 22, 2019; published online April 9, 2019.

Project supported by the National Natural Science Foundation of China (No. 41867053), and the Natural Science Foundation of Jiangxi Province (No. 20171ACB20025), the "5511" Science and Technology Innovation Talent Project of Jiangxi Province (No. 20165BCB18015), and the Project of the Science Funds of Jiangxi Education Office (No. GJJ180614).

国家自然科学基金(No. 41867053)、江西省自然科学基金(No. 2017ACB20025)、江西省 “5511” 科技创新人才工程(No. 20165BCB18015)和江西省教 育厅科学基金(No. GJJ180614)资助项目.
} 
for $\mathrm{Zn}^{2+}, \mathrm{CN}^{-}$, and $\mathrm{H}_{2} \mathrm{PO}_{4}^{-}$detection are becoming very urgent. Although, numerous chemosensors had been reported, the probe can identify the $\mathrm{CN}^{-}$and $\mathrm{Zn}^{2+}$ at the same time with different detection ways are rarely developed. In addition, as one of good photoswitch unit, diarylethene derivatives have been widely used in the design and synthesis of photochemical sensors due to their high sensitivity, real-time analysis and simple operation. ${ }^{[10]}$ During the past decades, many diarylethene chemosensors were reported to recognize $\mathrm{Zn}^{2+}$ or $\mathrm{CN}^{-}$. $^{[11]}$ However, photocontrolled diarylethene chemosensors can detect the $\mathrm{H}_{2} \mathrm{PO}_{4}^{-}, \mathrm{CN}^{-}$and $\mathrm{Zn}^{2+}$ at the same time and they are rarely.

Taking into account the above mentioned facts, a new diarylethene chemosensor (10) with a naphthol unit was synthesized and characterized, in which 2-hydroxybenzylidene-aminonaphthol was attached to a photochromic diarylethene as pendant ligand (Eq. 1). The compound exhibited "naked-eye" recognition of $\mathrm{CN}^{-}$, and remarkable "Turn-on" fluorescence response for detecting of $\mathrm{Zn}^{2+}$ with high selectivity. The schematic illustration of photochromism is shown in Figure 1.<smiles>Cc1noc(C)c1C1=C(c2cc(-c3ccc(O)c(C=O)c3)sc2C)C(F)(F)C(F)(F)C1(F)F</smiles><smiles>Cc1noc(C)c1C1=C(c2cc(-c3ccc(O)c(/C=N/c4cc5ccccc5cc4O)c3)sc2C)C(F)(F)C(F)(F)C1(F)F</smiles>
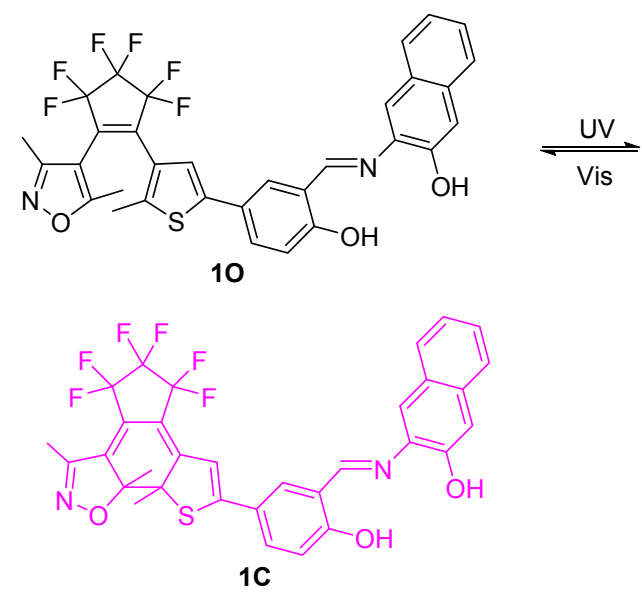

Figure 1 Photochromism of diarylethene 10

\section{Results and discussion}

\subsection{Photochromic properties of diarylethene 10}

The photochromic behaviors of diarylethene $\mathbf{1 0}$ were tested by photoirradiation in acetonitrile $\left(c=2.0 \times 10^{-5}\right.$ $\mathrm{mol} \cdot \mathrm{L}^{-1}$ ) at $297 \mathrm{~K}$. As shown in Figure 2, owing to the $\pi \rightarrow \pi^{*}$ transition, a sharp opened-ring isomer (10) absorption peak was observed at $274 \mathrm{~nm}\left(\varepsilon_{\max }=5.05 \times 10^{4}\right.$ $\left.\mathrm{L} \cdot \mathrm{mol}^{-1} \cdot \mathrm{cm}^{-1}\right)$. The peak of the open-ring isomer at 274 $\mathrm{nm}$ was declined slowly with irradiation of $297 \mathrm{~nm}$ UV light, meanwhile, a new broad absorption peak at $516 \mathrm{~nm}$ was gradually appeared $\left(\varepsilon_{\max }=3.68 \times 10^{3} \mathrm{~L} \cdot \mathrm{mol}^{-1} \cdot \mathrm{cm}^{-1}\right)$ due to the $\pi$ electron delocalization, indicating the formation of the closed-ring form 1C. ${ }^{[12]}$ After arrived at the photostationary state (PSS), the color of $\mathbf{1 0}$ solution changed from colorless to light pink, and a clear isosbestic point was observed at $409 \mathrm{~nm}$, which supported the reversible two component photochromic reaction. Conversely, upon irradiation with visible light of wavelength longer than $500 \mathrm{~nm}$, the closed-ring isomer $\mathbf{1 C}$ was reversed back to $\mathbf{1 0}$ accompanying with the solution color changed from pink to colorless. The cyclization and cycloreversion quantum yields of $\mathbf{1 0}$ were determined by using the 1,2-bis(2-methyl-5-phenyl-3-thienyl)perfluorocyclopentene as reference, and it values were determined to be 0.037 and 0.20 , which was smaller than $20\left(\Phi_{2}\right.$, O-C $\left.=0.21\right)$. The results demonstrate that the amino-naphthol group could inhibit the photocyclization of $\mathbf{1 0}$, the reason may be due to its strong electron-withdrawing property.

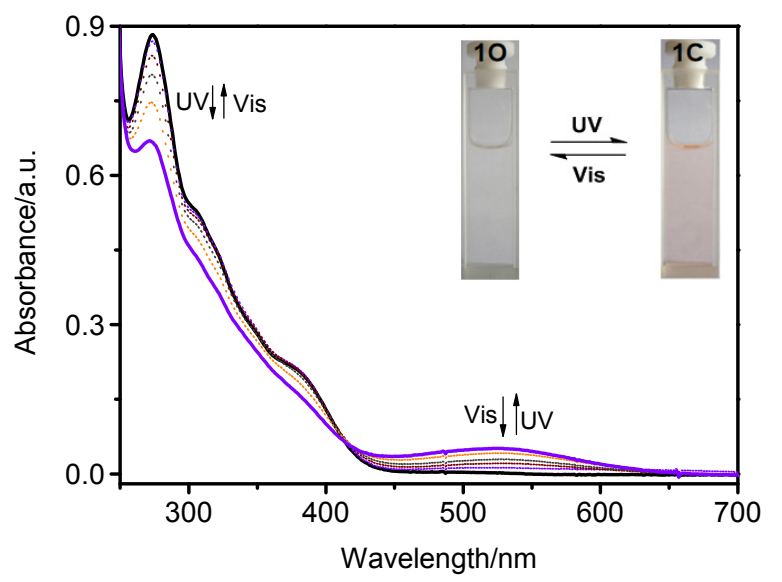

Figure 2 Absorption spectral and color changes of diarylethene 10 by photoirradiation in acetonitrile $\left(c=2.0 \times 10^{-5} \mathrm{~mol} \cdot \mathrm{L}^{-1}\right)$

\subsection{Colorimetric detection for $\mathrm{CN}^{-}$}

The photophysical properties of colorimetric sensing ability of diarylethene $\mathbf{1 0}$ were investigated by monitoring the absorption spectral behavior upon the addition of various anions, such as $\mathrm{CN}^{-}, \mathrm{F}^{-}, \mathrm{Cl}^{-}, \mathrm{Br}^{-}, \mathrm{SCN}^{-}, \mathrm{AcO}^{-}$, $\mathrm{CO}_{3}^{2-}, \mathrm{SO}_{3}^{2-}, \mathrm{SO}_{4}^{2-}, \mathrm{PO}_{4}^{3-}, \mathrm{S}_{2} \mathrm{O}_{3}^{2-}, \mathrm{HCO}_{3}^{-}, \mathrm{HSO}_{3}^{-}$, $\mathrm{HPO}_{4}^{2-}, \mathrm{HSO}_{4}^{2-}$ and $\mathrm{H}_{2} \mathrm{PO}_{4}^{-}$in acetonitrile $(0.2 \mu \mathrm{mol} \bullet$ $\left.\mathrm{L}^{-1}\right)$. Figure $3 \mathrm{~A}$ shows variations of the absorption spectra of 10 in acetonitrile in the presence of different anions. It is clear that 10 shows an absorption band centered at 490 $\mathrm{nm}$ upon the addition of $\mathrm{CN}^{-}$and $\mathrm{F}^{-}$, while other anions have no effect on its absorption spectra. The results indicated that 10 could efficient detection $\mathrm{CN}^{-}$and $\mathrm{F}^{-}$with good sensitivity over other anions in acetonitrile. Figure 
3B exhibited that with increasing concentration of $\mathrm{CN}^{-}$, the absorbance of $\mathbf{1 0}$ at $490 \mathrm{~nm}$ gradually enhanced. After addition of $24.0 \mu \mathrm{mol} \cdot \mathrm{L}^{-1}$ of $\mathrm{CN}^{-}$, the absorption intensity of $\mathbf{1 0}$ arrived at a plateau accompanied with a notable color change from colorless to orange due to the formation of $10+\mathrm{CN}^{-}$. Figure $3 \mathrm{~B}$ inset displayed a good linear calibration curve between absorbance at $490 \mathrm{~nm}$ and concentration of $\mathrm{CN}^{-}$, indicating that $\mathbf{1 0}$ could be potentially used as a ratiometric colorimetric sensor for quantitatively detecting $\mathrm{CN}^{-}$at the range of $0 \rightarrow 30.0 \mu \mathrm{mol} \cdot \mathrm{L}^{-1}$. Similar response to $\mathrm{F}^{-}$was observed under the same conditions for 10 (Figure 4). An obvious absorbance was gradually appeared at $490 \mathrm{~nm}$ and the color solution of $\mathbf{1 0}$ changed from colorless to orange with the stimulation of $\mathrm{F}^{-}$ $\left(0 \rightarrow 80.0 \mu \mathrm{mol} \cdot \mathrm{L}^{-1}\right)$. Figure 4 inset also exhibited a good linearity between the concentration of $\mathrm{F}^{-}$and the absorption in the range of $0 \rightarrow 48.0 \mu \mathrm{mol} \cdot \mathrm{L}^{-1}$, demonstrating that 10 could quantitatively detect $\mathrm{F}^{-}$at the relevant concentration.
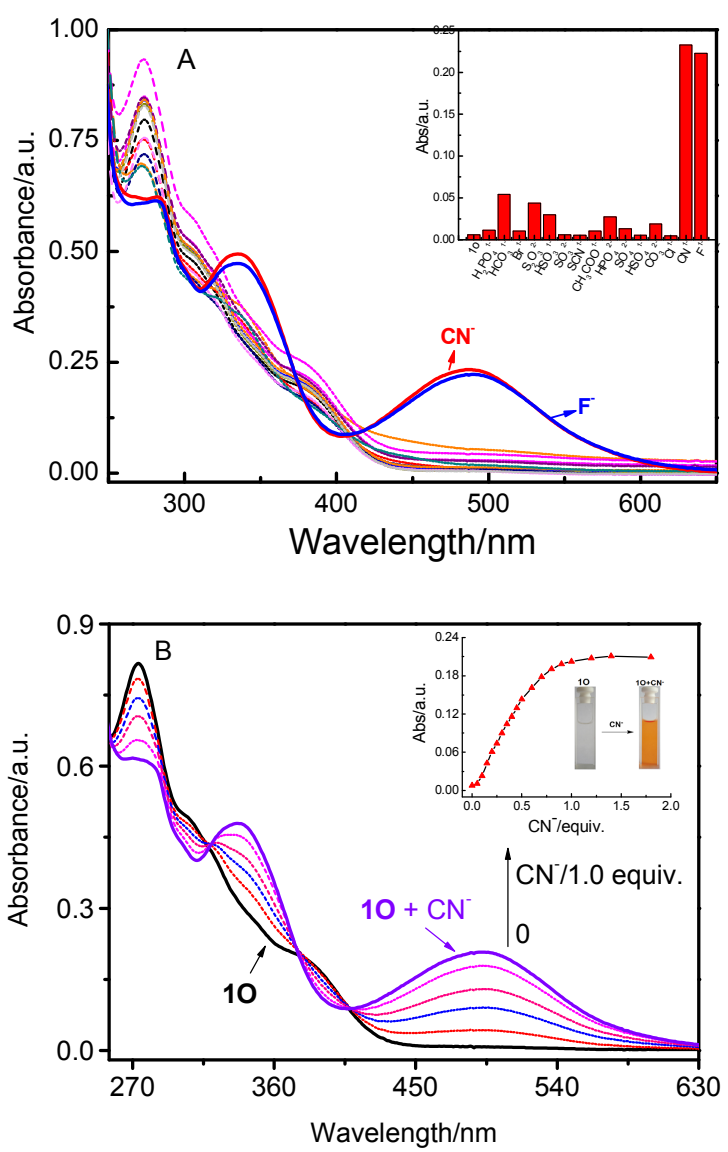

Figure 3 (A) Various anions induced the absorption of 10, and (B) changes in the absorption of $\mathbf{1 0}$ in the presence of different amount of $\mathrm{CN}^{-}$in acetonitrile

Inset: (A) the absorption intensity at $490 \mathrm{~nm}$ with the addition of different anions), and (B) the solution color and absorbance changes at $488 \mathrm{~nm}$ with the addition of $\mathrm{CN}^{-}$

The binding mode and stoichiometry of $\mathbf{1 0}$ to $\mathrm{CN}^{-} / \mathrm{F}^{-}$ were evaluated by Job's plot experiments, ${ }^{[13]}$ the absorbance at $490 \mathrm{~nm}$ was plotted as a function of the molar frac-

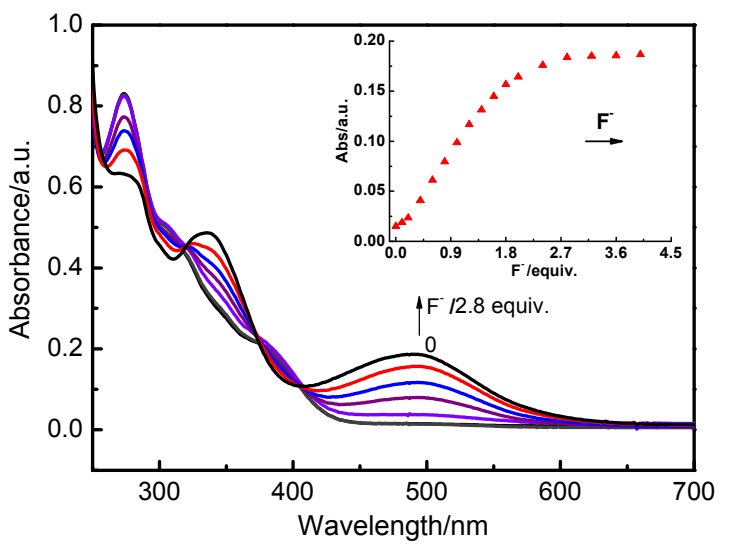

Figure 4 Absorption spectral changes of $\mathbf{1 0}$ in the presence of different amount of $\mathrm{F}^{-}$in acetonitrile

Inset was the solution color and absorbance changes at $488 \mathrm{~nm}$ with the addition of $\mathrm{F}^{-}$

tion of 10 under a constant total concentration at $2.0 \times$ $10^{-5} \mathrm{~mol} \cdot \mathrm{L}^{-1}$, and the changes of $\mathrm{CN}^{-} / \mathrm{F}^{-}$molar fraction from 0 to 1 (Figure 5). The results showed that the molar fraction of $[10] /\left[10+\mathrm{CN}^{-} / \mathrm{F}^{-}\right]$was 0.5 when the concentration of the complex $10+\mathrm{CN}^{-} / \mathrm{F}^{-}$arrived the maximum value, demonstrating $1: 1$ binding stoichiometry ration for $10+\mathrm{CN}^{-} / \mathrm{F}^{-}$. The results were further confirmed by the ${ }^{1} \mathrm{H}$ NMR titration experiments. It was found that two peaks
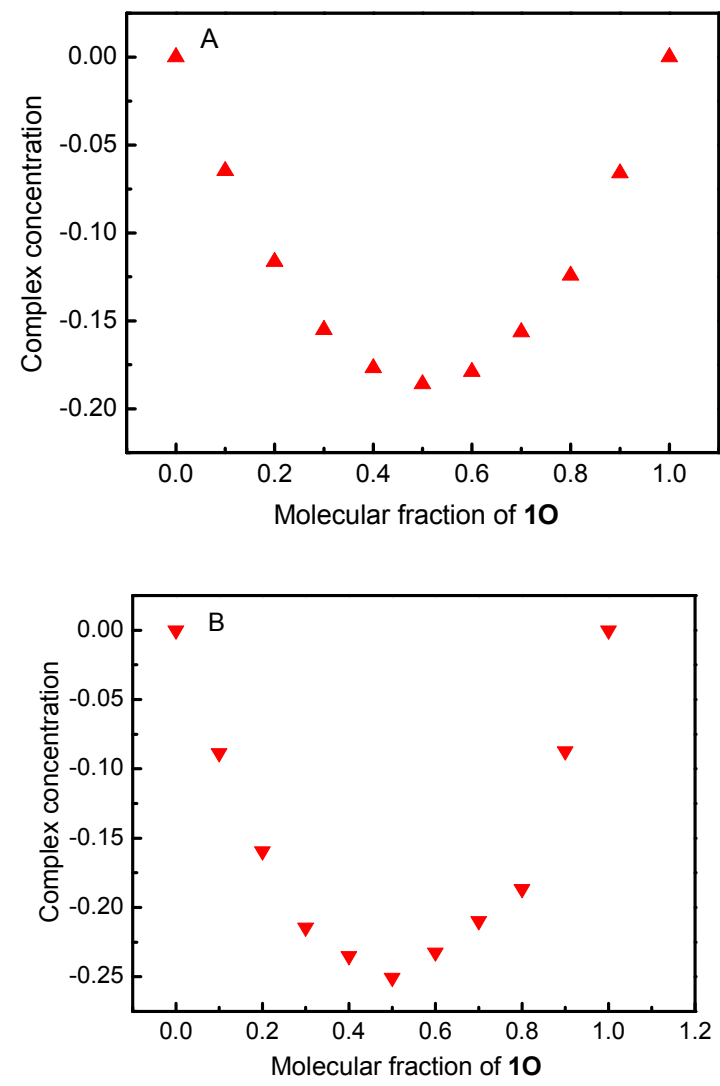

Figure 5 (A) Job's plot showing the $1: 1$ complex of (A) 10 with $\mathrm{CN}^{-}$, and (B) 10 with $\mathrm{F}^{-}$ 
at $8.73\left(\mathrm{H}^{a}\right.$, phenol-H) and $13.18\left(\mathrm{H}^{b}\right.$, naphthol- $\left.\mathrm{H}\right)$ were present in the ${ }^{1} \mathrm{H}$ NMR spectrum of $\mathbf{1 0}$ in $\mathrm{CD}_{3} \mathrm{CN}$ without $\mathrm{CN}^{-} / \mathrm{F}^{-}$. However, the signal peaks intensity at 8.73 and 13.18 gradually vanished accompany with the addition of $\mathrm{CN}^{-} / \mathrm{F}^{-}$to 10 , suggesting the formation of $10+\mathrm{CN}^{-} / \mathrm{F}^{-}$ compound. The binding constants $\left(K_{\mathrm{a}}\right)$ of 10 with $\mathrm{CN}^{-} / \mathrm{F}^{-}$ were determined to be $1.20 \times 10^{4}$ and $1.86 \times 10^{4} \mathrm{~L} \cdot \mathrm{mol}^{-1}$ according to the Hildebrand-Benesi experiments. ${ }^{[14]}$ The limit of detection (LOD) of $\mathbf{1 0}$ toward $\mathrm{CN}^{-} / \mathrm{F}^{-}$was calculated as $1.03 \times 10^{-6}$ and $3.43 \times 10^{-6} \mathrm{~mol} \cdot \mathrm{L}^{-1}$, respectively. Moreover, the competitive experiments of $\mathbf{1 0}+$ $\mathrm{CN}^{-} / \mathrm{F}^{-}$with various anions were carried out in order to estimate the specificity. As shown in Figure 6, there were no obvious changes in the absorbance of $10+\mathrm{CN}^{-} / \mathrm{F}^{-}$ when other anions were added to the solution containing $10+\mathrm{CN}^{-} / \mathrm{F}^{-}$except for $\mathrm{HSO}_{4}^{-}$and $\mathrm{CH}_{3} \mathrm{COO}^{-}$. Particularly, the absorbance and color of $\mathbf{1 0}+\mathrm{F}^{-}$could notably decrease and nearly bleach by stimulating with $\mathrm{HSO}_{4}{ }^{-}$and $\mathrm{CH}_{3} \mathrm{COO}^{-}$. These results indicated that $\mathbf{1 0}$ could be served as a high selectivity and sensitivity colorimetric probe to recognize $\mathrm{CN}^{-} / \mathrm{F}^{-}$.
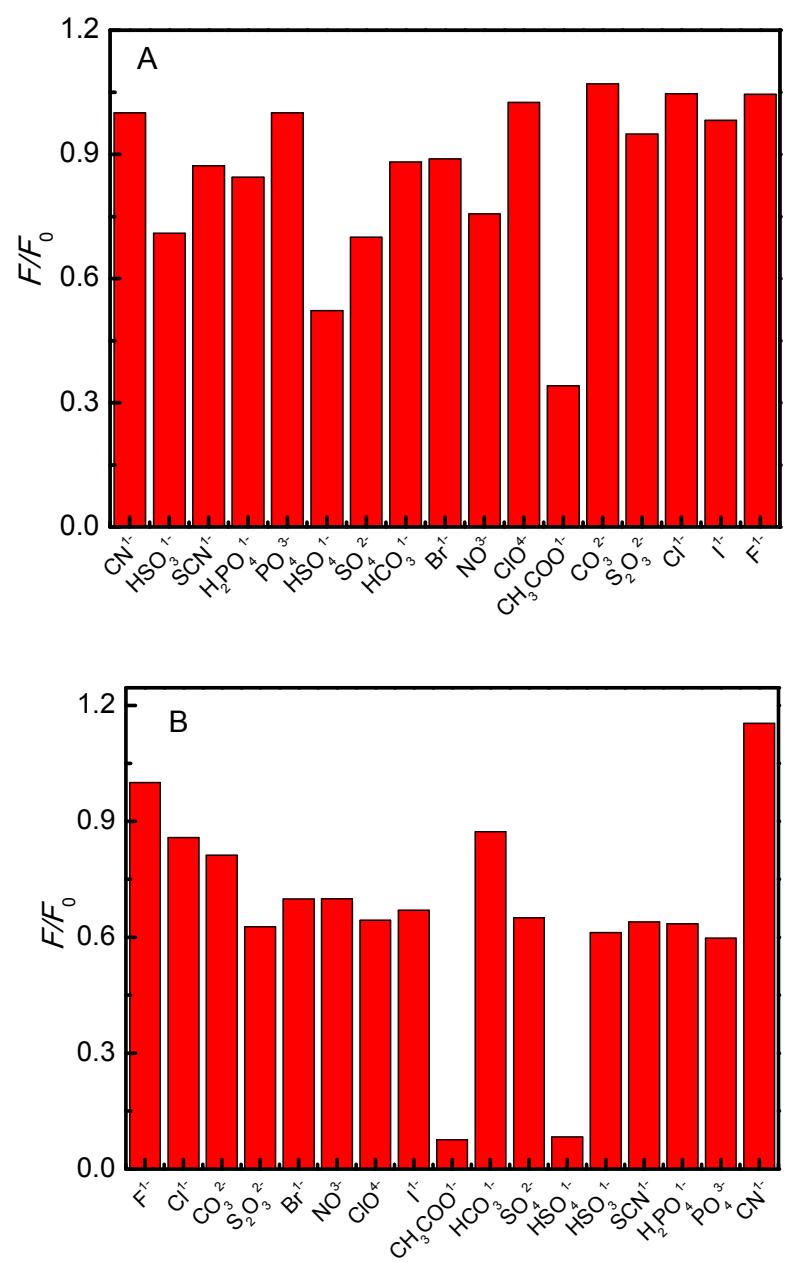

Figure 6 Competitive tests for the fluorescence responses of 10 induced by $\mathrm{CN}^{-}(\mathrm{A})$ and $\mathrm{F}^{-}(\mathrm{B})$ in the presence of other anions.

Subsequently, the photo-isomerization of $\mathbf{1 0}+\mathrm{CN}^{-}$ compound was studied by UV-Vis spectral absorption. As shown in Figure 7, upon irradiation with $313 \mathrm{~nm}$ light, the absorbance peaks at 338 and $490 \mathrm{~nm}$ were gradually decreased, and a new obvious visible absorption band ap-

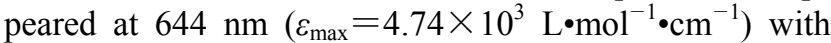
the orange solution turned to green. The reason may be ascribed to the formation of the closed-ring isomer $\mathbf{1 C}+$ $\mathrm{CN}^{-}$, which could be completely recovered to the original color and absorption spectrum of $\mathbf{1 0}+\mathrm{CN}^{-}$when irradiated with visible light $(\lambda>500 \mathrm{~nm})$.

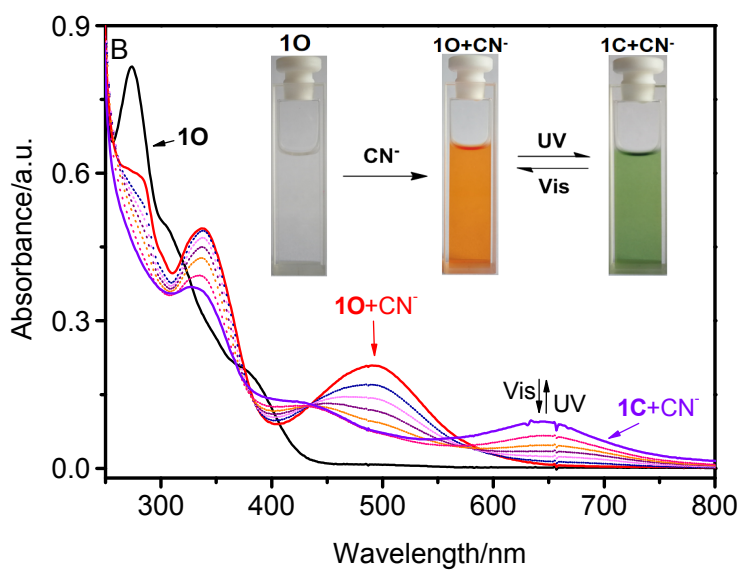

Figure 7 Absorption spectral changes of $10+\mathrm{CN}^{-}$by photoirradiation with UV/Vis light in acetonitrile Inset: the solution color changes

\subsection{Fluorescence studies of 10 toward $\mathrm{Zn}^{2+}$}

The interactions of $\mathbf{1 0}$ with various metal ions were also studied by fluorescence spectrum in acetonitrile $(c=2.0 \times$ $10^{-5} \mathrm{~mol} \cdot \mathrm{L}^{-1}$ ) (Figure $8 \mathrm{~A}$ ). It could be seen that $\mathbf{1 0}$ showed poorly fluorescent at $603 \mathrm{~nm}$. Upon the addition of $0.2 \mathrm{mmol} \cdot \mathrm{L}^{-1} \mathrm{Al}^{3+}, \mathrm{Zn}^{2+}, \mathrm{Mg}^{2+}, \mathrm{Cd}^{2+}, \mathrm{Fe}^{3+}, \mathrm{Co}^{2+}, \mathrm{Ni}^{2+}$, $\mathrm{Cu}^{2+}, \mathrm{Cr}^{3+}, \mathrm{Ca}^{2+}, \mathrm{Ba}^{2+}, \mathrm{Pb}^{2+}, \mathrm{Sr}^{2+}, \mathrm{Sn}^{2+}, \mathrm{Hg}^{2+}, \mathrm{Mn}^{2+}, \mathrm{K}^{+}$ and $\mathrm{Ag}^{+}$in acetonitrile, the fluorescence emission intensity of 10 exhibited no obvious changes. However, when stimulated by $\mathrm{Zn}^{2+}$, a strong emission peak was observed at $578 \mathrm{~nm}$ and the fluorescence color changed from dark to bright yellow (Figure 8B), indicating the formation of $10-\mathrm{Zn}^{2+}$ complex, which emission wavelength was distinct blue-shifted $25 \mathrm{~nm}$ comparison with 10. The complexation between 10 and $\mathrm{Zn}^{2+}$ induced that fluorescence enhancement features maybe attributed to the blocked $\mathrm{C}=$ $\mathrm{N}$ isomerization and chelated enhanced fluorescence (CHEF) effects. ${ }^{[15]}$

Further, in order to study the binding properties of $\mathbf{1 0}$ to $\mathrm{Zn}^{2+}$, the fluorescence titration experiments were performed. As shown in Figure 9A, the original fluorescence emission peak at $578 \mathrm{~nm}$ was gradually increased with increasing the concentration of $\mathrm{Zn}^{2+}\left(0 \rightarrow 1.4 \mathrm{mmol} \cdot \mathrm{L}^{-1}\right)$, and then the spectrum followed by a plateau with further titration. Compared to $\mathbf{1 0}$, the emission intensity of $10-\mathrm{Zn}^{2+}$ was enhanced 32-fold, and the fluorescence quantum yield was determined to be 0.15 . The corresponding binding constant was estimated to be $3.03 \times 10^{3}$ 

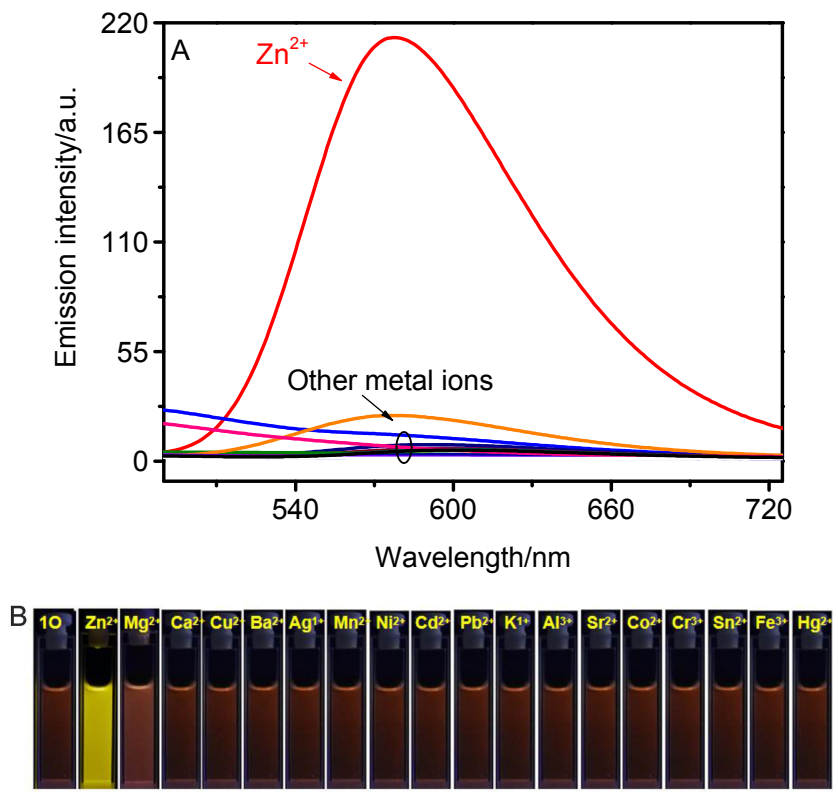

Figure 8 Changes in the fluorescence of $\mathbf{1 0}$ induced by the addition of various metal ions $\left(0.5 \mathrm{mmol} \cdot \mathrm{L}^{-1}\right)$ in acetonitrile $\left(c=2.0 \times 10^{-5} \mathrm{~mol} \cdot \mathrm{L}^{-1}\right)$

(A) Emission spectra; (B) photographs of fluorescence
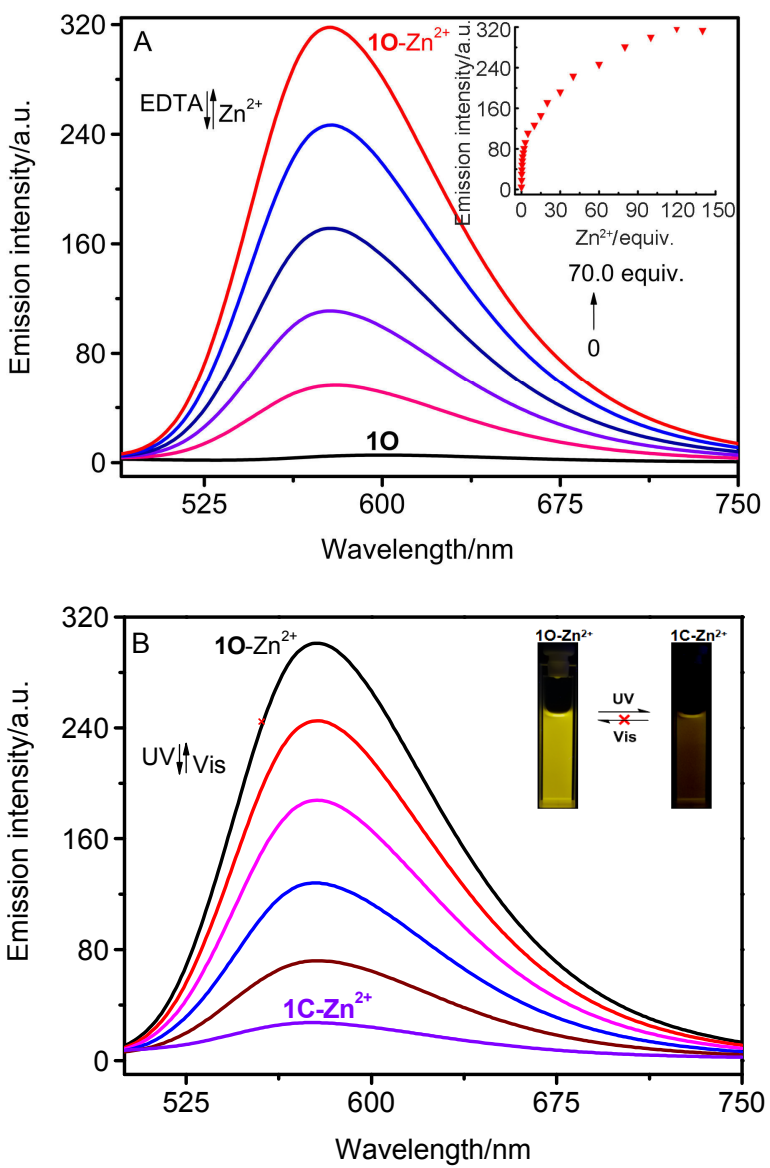

Figure 9 (A) Changes in fluorescence of 10 induced by $\mathrm{Zn}^{2+}$ / EDTA, and (B) changes in emission intensity of $10-\mathrm{Zn}^{2+}$ by photo irradiation

Inset: its emission intensity curve at $578 \mathrm{~nm}$ with the addition of different concentration of $\mathrm{Zn}^{2+}$
$\mathrm{L} \cdot \mathrm{mol}^{-1}$, and the limit of detection (LOD) was calculated to be $2.98 \times 10^{-8} \mathrm{~mol} \cdot \mathrm{L}^{-1}$. Notably, the fluorescence intensity of $10-\mathrm{Zn}^{2+}$ could completely restore when added excessive EDTA aqueous solution, demonstrating that EDTA binding with $\mathrm{Zn}^{2+}$ was stronger than $\mathbf{1 0}$ in acetonitrile. Furthermore, the strong fluorescence emission band of $10-\mathrm{Zn}^{2+}$ at $578 \mathrm{~nm}$ could switch off by irradiating with $313 \mathrm{~nm}$ light because the formation of the non-fluorescence closed-ring isomer $\mathbf{1 C}-\mathrm{Zn}^{2+}$ (Figure 9B). The fluorescence of $10-\mathrm{Zn}^{2+}$ was quenched to $91 \%$ and the bright yellow solution became dark when the photoisomerization reaction arrived at the PSS. It is worth noting that the fluorescence of $1 \mathrm{C}-\mathrm{Zn}^{2+}$ can not be restored to the initial state under the exposure with visible light. The results indicated that $\mathbf{1 0}$ could be used as an "off-on-off" fluorescence switch under the dual regulation of $\mathrm{Zn}^{2+}$ and $313 \mathrm{~nm}$ light.

Subsequently, Job's plot curve and ${ }^{1} \mathrm{H}$ NMR spectra experiments were carried out to determine the binding mode between 10 and $\mathrm{Zn}^{2+}$. As shown in Figure 10A, the complex concentration got the maximum when the molecular fraction of 10 reached 0.7 , suggesting $2: 1$ stoichiometric complexation between 10 and $\mathrm{Zn}^{2+}$. These data were further supported by ${ }^{1} \mathrm{H}$ NMR titration analysis of $10-\mathrm{Zn}^{2+}$ complex formation (Figure 10B). It was clearly seen that the peak intensity of $\mathrm{OH}^{a}$ (naphthol- $\mathrm{H}^{a}$ ) at 13.77 was gradually disappeared with increasing $\mathrm{Zn}^{2+}$ from 0 to 0.4 $\mathrm{mmol} \cdot \mathrm{L}^{-1}$. While the chemical shifts of $\mathrm{OH}^{b}$ (phenol- $\left.\mathrm{H}^{b}\right)$ at 9.48 and $\mathrm{CH}^{c}\left(\mathrm{CH}^{c}=\mathrm{N}\right)$ at 8.98 undergo an upfield shift to 9.22 and 8.80 , respectively. Meanwhile, two new signals were observed at 10.66 and 9.81 , corresponding to the $\mathrm{OH}^{b^{\prime}}$ (phenol- $\left.\mathrm{H}^{b^{\prime}}\right)$ and $\mathrm{CH}^{c^{\prime}}\left(\mathrm{CH}^{c^{\prime}}=\mathrm{N}\right)$. These results further confirmed that the stoichiometric ratio between 10 and $\mathrm{Zn}^{2+}$ were $2: 1$. Based on these a plausible binding scheme was presented in Scheme 1, where the oxygen atoms of phenol/naphthol and the nitrogen atoms of $\mathrm{C}=\mathrm{N}$ double bond are the most chelating atoms and participated in the complexation.

Figure 11A shows the selectivity of the fluorescence response of $10-\mathrm{Zn}^{2+}$ to various anions in acetonitrile $(c=$ $\left.2.0 \times 10^{-5} \mathrm{~mol} \cdot \mathrm{L}^{-1}\right)$. The emission spectral of $10-\mathrm{Zn}^{2+}$ induced by anions $\left(0.1 \mathrm{mmol} \cdot \mathrm{L}^{-1}\right)$ such as $\mathrm{CN}^{-}, \mathrm{F}^{-}, \mathrm{Cl}^{-}$, $\mathrm{Br}^{-}, \mathrm{SCN}^{-}, \mathrm{AcO}^{-}, \mathrm{CO}_{3}^{2-}, \mathrm{SO}_{3}^{2-}, \mathrm{SO}_{4}^{2-}, \mathrm{PO}_{4}^{3-}, \mathrm{S}_{2} \mathrm{O}_{3}^{2-}$, $\mathrm{HCO}_{3}^{-}, \mathrm{HSO}_{3}^{-}, \mathrm{HSO}_{4}^{-}, \mathrm{HPO}_{4}^{2-}$ and $\mathrm{H}_{2} \mathrm{PO}_{4}^{-}$. It could be seen that no obvious effects on the fluorescence intensity of $10-\mathrm{Zn}^{2+}$ when $\mathrm{Cl}^{-}, \mathrm{Br}^{-}, \mathrm{SCN}^{-}, \mathrm{SO}_{3}^{2-}, \mathrm{SO}_{4}^{2-}$, $\mathrm{S}_{2} \mathrm{O}_{3}^{2-}, \mathrm{HSO}_{3}^{-}$, and $\mathrm{H}_{2} \mathrm{PO}_{4}^{-}$were added to $\mathbf{1 0}-\mathrm{Zn}^{2+}$ solution $\left(0.5 \mathrm{mmol} \cdot \mathrm{L}^{-1}\right)$. While $\mathrm{CN}^{-}, \mathrm{F}^{-}, \mathrm{AcO}^{-}, \mathrm{CO}_{3}^{2-}$, $\mathrm{PO}_{4}^{3-}$ and $\mathrm{HCO}_{3}^{-}$can induce its fluorescence intensity decrease to some extent. Notably, when $\mathrm{H}_{2} \mathrm{PO}_{4}^{-}$and $\mathrm{HSO}_{4}^{-}$were added to the acetonitrile solution containing $10-\mathrm{Zn}^{2+}$, the fluorescence intensity of $10-\mathrm{Zn}^{2+}$ was quenched to $97 \%$ and $94 \%$, respectively, with an obvious color change from bright yellow to dark (Figure 11B). The results demonstrated that $\mathbf{1 0}-\mathrm{Zn}^{2+}$ complex could be served as a good probe to detect $\mathrm{H}_{2} \mathrm{PO}_{4}^{-}$and $\mathrm{HSO}_{4}^{-}$. In 

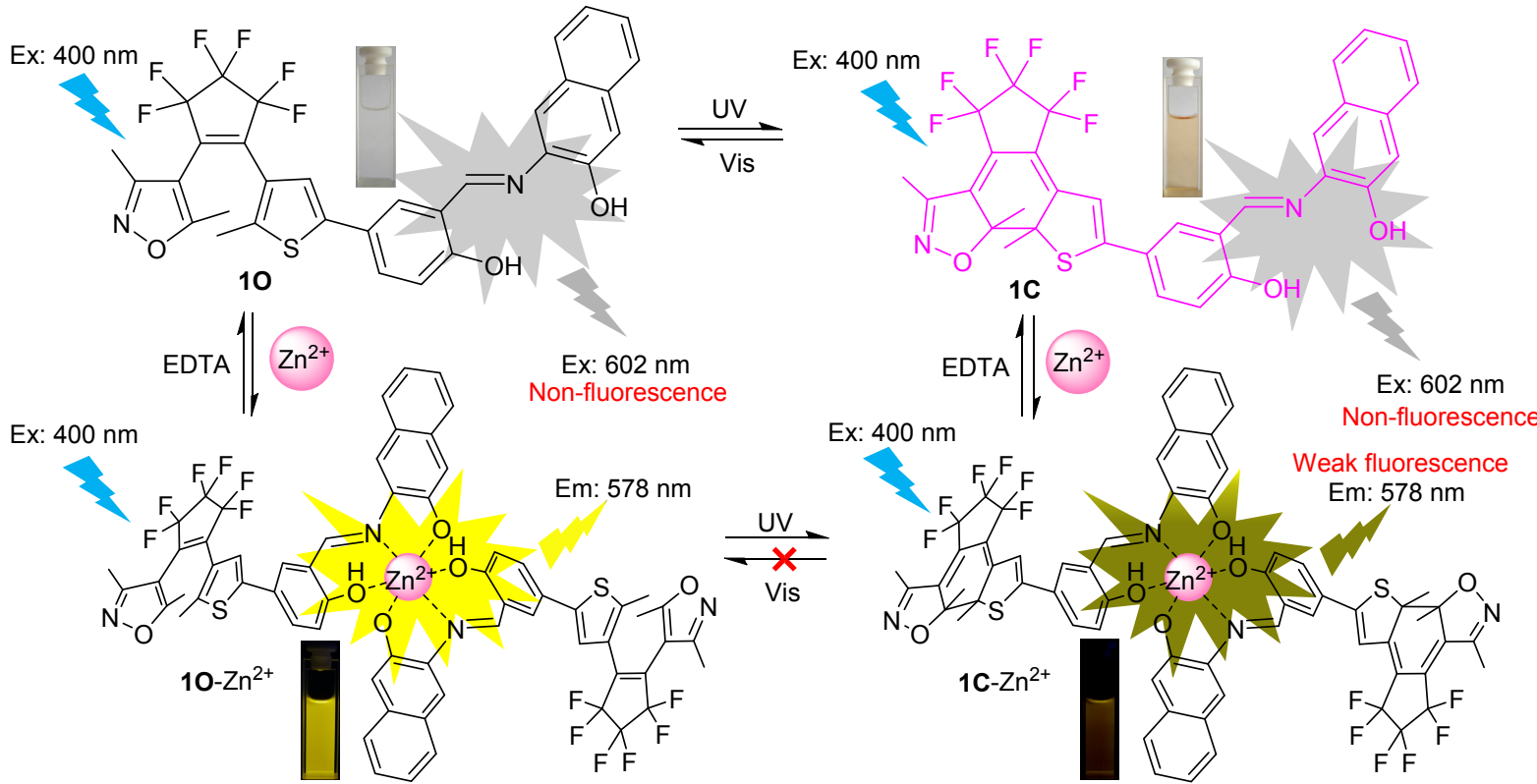

Scheme 1 Photochromism and fluorescence changes of 10 induced by $\mathrm{Zn}^{2+}$, EDTA and lights.
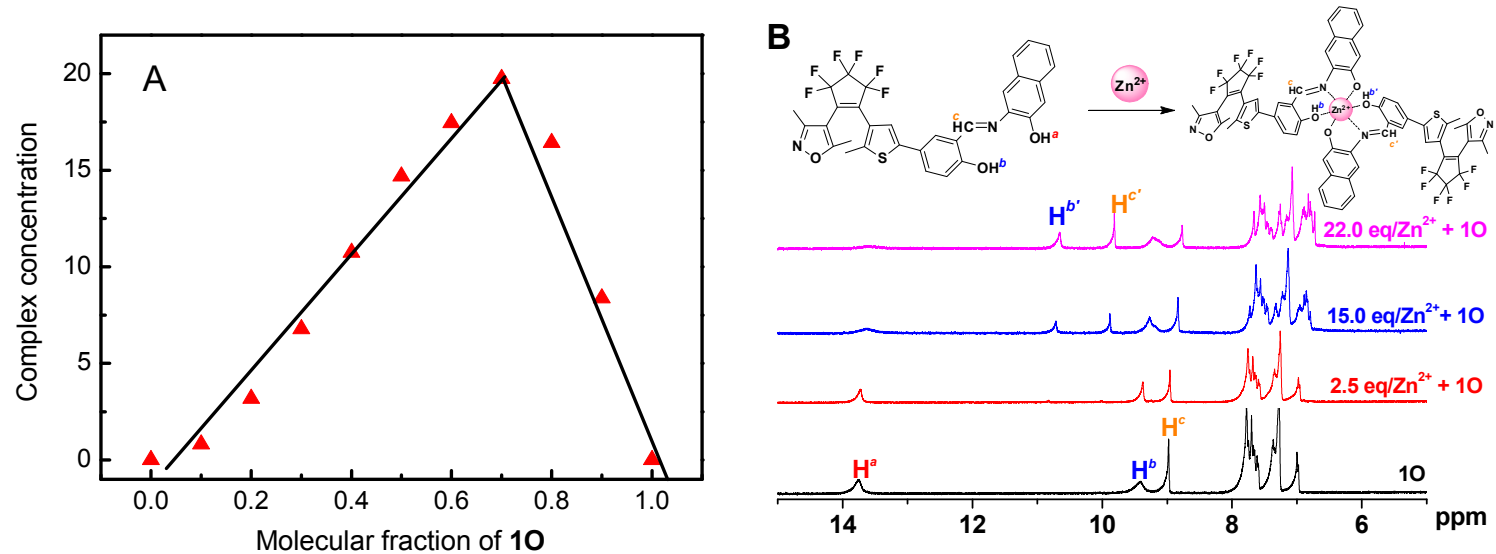

Figure 10 (A) Job's plot showing the $2: 1$ complex of $\mathbf{1 0}$ with $\mathrm{Zn}^{2+}$, and (B) ${ }^{1} \mathrm{H}$ NMR spectra of $\mathbf{1 0}$ in the presence of $\mathrm{Zn}^{2+}(0 \rightarrow 0.4$ $\mathrm{mmol} \cdot \mathrm{L}^{-1}$ ) in acetonitrile
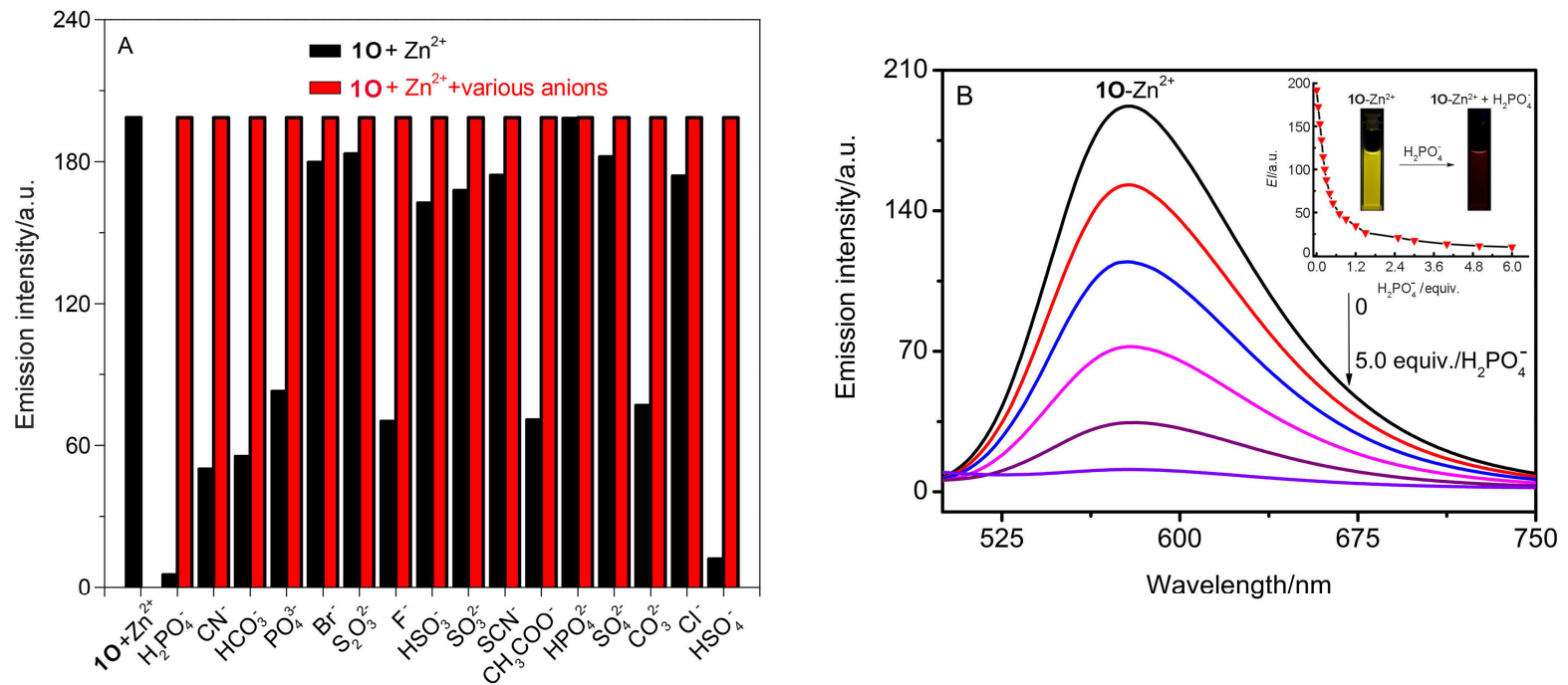

Figure 11 (A) Changes in fluorescence of $10-\mathrm{Zn}^{2+}$ induced by different anions, and (B) changes in emission intensity of $10-\mathrm{Zn}^{2+}$ upon the addition of $\mathrm{H}_{2} \mathrm{PO}_{4}^{-}$

Inset: its emission intensity curve at $578 \mathrm{~nm}$ with the addition of different concentration of $\mathrm{H}_{2} \mathrm{PO}_{4}$ 
a fluorometric titration, addition of $\mathrm{H}_{2} \mathrm{PO}_{4}^{-}$to the solution of $10-\mathrm{Zn}^{2+}$ resulted in a gradually decrease of the emission intensity centered at $578 \mathrm{~nm}$. By plotting the fluorescence intensity at $578 \mathrm{~nm}$ as a function of $\mathrm{H}_{2} \mathrm{PO}_{4}^{-}$ concentration $\left(0 \rightarrow 20 \mu \mathrm{mol} \cdot \mathrm{L}^{-1}\right)$, a good relationship curve was obtained (Figure 11B). Similarly, $\mathrm{HSO}_{4}^{-}$can also turn off the fluorescence emission intensity of $10-\mathrm{Zn}^{2+}$. The results indicated that $10-\mathrm{Zn}^{2+}$ could be potentially used as ratiometric fluorescent sensor for recognizing $\mathrm{H}_{2} \mathrm{PO}_{4}^{-} / \mathrm{HSO}_{4}^{-}$. Furthermore, the association constants were calculated to be $8.29 \times 10^{4}{\mathrm{~L} \cdot \mathrm{mol}^{-1}}^{-1}(R=0.993)$ for $\mathrm{H}_{2} \mathrm{PO}_{4}^{-}$and $6.86 \times 10^{4} \mathrm{~L} \cdot \mathrm{mol}^{-1}(R=0.997)$ for $\mathrm{HSO}_{4}^{-}$ according to a Benesi-Hildebrand plot, and the LOD of 10- $\mathrm{Zn}^{2+}$ for detecting $\mathrm{H}_{2} \mathrm{PO}_{4}^{-} / \mathrm{HSO}_{4}^{-}$were estimated to be $6.55 \times 10^{-7}$ and $1.27 \times 10^{-7} \mathrm{~mol} \cdot \mathrm{L}^{-1}$, respectively.

Subsequently, in order to comparison with reported chemosensors, some recently published related studies were summarized in Table 1, and some important parameters such as the LOD and binding constants, and stokes shift values. It could be seen that $\mathbf{1 0}$ had lower LOD value for detecting $\mathrm{Zn}^{2+}$, and high sensitivity in the range of $10^{-7}$ for recognizing $\mathrm{H}_{2} \mathrm{PO}_{4}^{-}$. The binding constant of 10 was of the order $10^{3}$ for $\mathrm{Zn}^{2+}$, which was the small level compared to other probes. However, diarylethene 10 could effectively recognize both $\mathrm{CN}^{-}$and $\mathrm{H}_{2} \mathrm{PO}_{4}^{-}$with the normal level binding constants $\left(10^{4}\right)$, the multi sensing characteristics of $\mathbf{1 0}$ had much more advantages than other probes. The results provided a useful design strategy for constructing a multi-functional probe for the selective recognition based on unimolecule photochromic diarylethene with a certain functionalized group.

\section{Conclusions}

In conclusion, a new colorimetric and fluorometric diarylethene sensor containing a 2-hydroxybenzylidene-aminonaphthol group had been developed. The compound exhibited "naked-eye" detection for $\mathrm{CN}^{-}$with high selectivity and lower LOD in acetonitrile. Meanwhile, it also showed highly sensitively for detecting $\mathrm{Zn}^{2+}$ with a $2: 1$ binding stoichiometry, and the LOD for $\mathrm{Zn}^{2+}$ reached to $0.3 \mathrm{nmol} \cdot \mathrm{L}^{-1}$. Additionally, the $\mathbf{1 0}-\mathrm{Zn}^{2+}$ complex could efficiently recognize $\mathrm{H}_{2} \mathrm{PO}_{4}^{-} / \mathrm{HSO}_{4}^{-}$with the LOD of $6.55 \times 10^{-7}$ and $1.27 \times 10^{-7} \mathrm{~mol} \cdot \mathrm{L}^{-1}$, respectively. These results suggested that $\mathbf{1 0}$ could be used as an efficient

Table 1 Comparative study of the analytical performance of 10 with other reported sensors

\begin{tabular}{|c|c|c|c|c|}
\hline Ref. & Sensor & Binding constant $K_{\mathrm{a}} /\left(\mathrm{L} \cdot \mathrm{mol}^{-1}\right)$ & $\mathrm{LOD} /\left(\mathrm{L} \cdot \mathrm{mol}^{-1}\right)$ & Stokes shift $/ \mathrm{nm}$ \\
\hline [16] & & $3.07 \times 10^{3}\left(\mathrm{Zn}^{2+}\right)$ & $1.22 \times 10^{-6}\left(\mathrm{Zn}^{2+}\right)$ & $30 \mathrm{~nm}$ \\
\hline [17] & & $1.90 \times 10^{5}\left(\mathrm{Zn}^{2+}\right)$ & $6.85 \times 10^{-8}\left(\mathrm{Zn}^{2+}\right)$ & $28 \mathrm{~nm}$ \\
\hline [18] & & $2.50 \times 10^{6}\left(\mathrm{Zn}^{2+}\right)$ & $4.90 \times 10^{-8}\left(\mathrm{Zn}^{2+}\right)$ & $64 \mathrm{~nm}$ \\
\hline [19] & & $1.17 \times 10^{4}\left(\mathrm{Zn}^{2+}\right)$ & $4.90 \times 10^{-8}\left(\mathrm{Zn}^{2+}\right)$ & $23 \mathrm{~nm}$ \\
\hline This work & & $\begin{array}{l}3.03 \times 10^{3}\left(\mathrm{Zn}^{2+}\right) \\
1.20 \times 10^{4}\left(\mathrm{CN}^{-}\right) \\
8.29 \times 10^{4}\left(\mathrm{H}_{2} \mathrm{PO}_{4}^{-}\right)\end{array}$ & $\begin{array}{l}2.98 \times 10^{-8}\left(\mathrm{Zn}^{2+}\right) \\
1.03 \times 10^{-6}\left(\mathrm{CN}^{-}\right) \\
6.55 \times 10^{-7}\left(\mathrm{H}_{2} \mathrm{PO}_{4}^{-}\right)\end{array}$ & $25 \mathrm{~nm}$ \\
\hline
\end{tabular}


multifunctional sensor for detecting $\mathrm{CN}^{-}, \mathrm{H}_{2} \mathrm{PO}_{4}^{-}$, and $\mathrm{Zn}^{2+}$.

\section{Experimental section}

\subsection{General methods}

All solvents were of analytical grade and used without further purification. Other reagents were used as-received. ${ }^{1} \mathrm{H}$ NMR and ${ }^{13} \mathrm{C}$ NMR spectra were measured with a Bruker AVANCE NEO $500 \mathrm{MHz}$ FT-NMR spectrometer (tetramethylsilane as the internal standard). Mass spectra were collected using an Agilent 1100 ion trap LC/MS MSD system. Metal ions, such as $\mathrm{Al}^{3+}, \mathrm{Zn}^{2+}, \mathrm{Mg}^{2+}, \mathrm{Fe}^{3+}$, $\mathrm{Co}^{2+}, \mathrm{Ni}^{2+}, \mathrm{Cu}^{2+}, \mathrm{Cr}^{3+}, \mathrm{Ca}^{2+}, \mathrm{Pb}^{2+}, \mathrm{Sr}^{2+}, \mathrm{Mn}^{2+}$ and $\mathrm{Ag}^{+}$ were prepared by dissolving the corresponding metal nitrates $(0.1 \mathrm{mmol})$ in distilled water $(2.0 \mathrm{~mL})$, other metal ions like $\mathrm{Ba}^{2+}, \mathrm{Cd}^{2+}, \mathrm{Hg}^{2+}, \mathrm{Sn}^{2+}$, and $\mathrm{K}^{+}$were prepared with their chlorides. Anions, except $\mathrm{CO}_{3}^{2-}, \mathrm{SO}_{3}^{2-}$, $\mathrm{SO}_{4}^{2-}, \mathrm{PO}_{4}^{3-}, \mathrm{S}_{2} \mathrm{O}_{3}^{2-}, \mathrm{HCO}_{3}^{-}, \mathrm{HSO}_{3}^{-}, \mathrm{HSO}_{4}^{-}$, $\mathrm{HPO}_{4}^{2-}$ and $\mathrm{H}_{2} \mathrm{PO}_{4}^{-}$that were prepared with their sodium salts, remaining anions $\left(\mathrm{CN}^{-}, \mathrm{F}^{-}, \mathrm{Cl}^{-}, \mathrm{Br}^{-}, \mathrm{SCN}^{-}\right.$ and $\left.\mathrm{AcO}^{-}\right)$were obtained by their tetrabutylammonium salts $(0.1 \mathrm{mmol})$ in distilled water $(2.0 \mathrm{~mL})$. EDTA solution was gained with ethylenediaminetetraacetic acid disodium salt $\left(\mathrm{Na}_{2} \mathrm{EDTA}\right)(1.0 \mathrm{mmol})$ in distilled water $(10.0$ $\mathrm{mL})$. Hitachi F-4500 fluorescence spectrophotometer and Agilent 8454 were used in performing fluorescence spectra and UV/Vis photoirradiation with an MUL-165 UV lamp and MVL-210 visible lamp. Melting point was determined using a WRS-1B melting point apparatus. Elemental analysis was studied by a PE CHN 2400 analyzer. Photoirradiation experiments were performed on a setup consisting of an SHG-200 UV lamp, CX-21 ultraviolet fluorescence analysis cabinet, and $\mathrm{BMH}-250$ visible lamp.

4.2 Synthesis of 1-(3,5-dimethylisoxazole-4-yl)-2-(2methyl-5-[(3-aminonaphthol-2-yl)phenol-yl]-thiophene-3-yl)perfluorocyclopentene (10)

1-(3,5-dimethyl-4-isoxazol)-2-(2-methyl-5-[4-hydroxy3-aldehyde]-thiophene-3-yl)perfluorocyclopentene (2) was synthesized following a series of previously reported methods. ${ }^{[20]}$

In a $100 \mathrm{~mL}$ flask, a mixture of diarylethene (2) $(0.24 \mathrm{~g}$, $0.5 \mathrm{mmol}), 2$-aminonaphthol (3) $(0.08 \mathrm{~g}, 0.5 \mathrm{mmol})$ in anhydrous ethanol $(5.0 \mathrm{~mL})$ was stirred and refluxed for $6 \mathrm{~h}$. After cooling the mixture solution to the room temperature, the crude product was washed several times with ethanol and diethyl ether, and dried under vacuum to afford $0.20 \mathrm{~g}$ (64\% yield) 10 as a red solid. m.p. $215 \sim 216{ }^{\circ} \mathrm{C} ;{ }^{1} \mathrm{H}$ NMR (500 MHz, DMSO- $\left.d_{6}\right) \delta: 13.82(\mathrm{~s}, 1 \mathrm{H}), 10.14(\mathrm{~s}$, $1 \mathrm{H}), 9.14(\mathrm{~s}, 1 \mathrm{H}), 7.99(\mathrm{~s}, 1 \mathrm{H}), 7.84(\mathrm{~s}, 1 \mathrm{H}), 7.78(\mathrm{~d}, J=$ $5.0 \mathrm{~Hz}, 1 \mathrm{H}), 7.69 \sim 7.66(\mathrm{~m}, 2 \mathrm{H}), 7.42(\mathrm{~s}, 1 \mathrm{H}), 7.36(\mathrm{t}, J=$ $15.0 \mathrm{~Hz}, 1 \mathrm{H}), 7.28(\mathrm{t}, J=15.0 \mathrm{~Hz}, 2 \mathrm{H}), 7.01(\mathrm{~d}, J=5.0 \mathrm{~Hz}$, 1H), 2.25 (s, 3H), $2.02(\mathrm{~s}, 3 \mathrm{H}), 1.97(\mathrm{~s}, 3 \mathrm{H}) ;{ }^{13} \mathrm{C} \mathrm{NMR}$ $\left(126 \mathrm{MHz}, \mathrm{DMSO}-d_{6}\right) \quad \delta$ : 10.72, 12.27, 14.58, 104.45, $110.44,117.62,118.32,120.16,121.70,123.94,124.66$, $126.25,126.57,128.40,129.53,130.87,133.86,140.97$, $142.22,150.49,158.57,161.64,162.99,170.76$; ESI-MS $m / z: 629.09[\mathrm{M}+\mathrm{H}]^{+}$. Anal. calcd for $\mathrm{C}_{32} \mathrm{H}_{22} \mathrm{~F}_{6} \mathrm{~N}_{2} \mathrm{O}_{3} \mathrm{~S}: \mathrm{C}$ 61.14, H 3.53, N 4.46; found C 61.12, H 3.55, N 4.44.

Supporting Information ${ }^{1} \mathrm{H}$ NMR spectra of $\mathbf{1 0}$ in DMSO, ${ }^{13} \mathrm{C}$ NMR spectra of $\mathbf{1 0}$ in DMSO and ESI-MS spectra of 10 in $\mathrm{CH}_{3} \mathrm{CN}$. ${ }^{1} \mathrm{H}$ NMR titration of $\mathbf{1 0}$ in the presence of $\mathrm{CN}^{-}$and $\mathrm{F}^{-}$, the binding constant between 10 $+\mathrm{CN}^{-} / \mathrm{F}^{-}$, the limit of detection (LOD) of $\mathrm{CN}^{-}$and $\mathrm{F}^{-}$, the binding constant for $10-\mathrm{Zn}^{2+}$ and the limit of detection (LOD), changes in emission intensity of $\mathbf{1 0}-\mathrm{Zn}^{2+}$ upon the addition of different amount of $\mathrm{HSO}_{4}^{-}$, the binding constant for $10-\mathrm{Zn}^{2+}$ with $\mathrm{H}_{2} \mathrm{PO}_{4}^{-}$and $\mathrm{HSO}_{4}^{-}$, the limit of detection (LOD) of $\mathrm{H}_{2} \mathrm{PO}_{4}^{-}$and $\mathrm{HSO}_{4}^{-}$. The Supporting Information is available free of charge via the Internet at http://sioc-journal.cn/.

\section{References}

[1] (a) Williams, R. J. P. The Biological Chemistry of the Elements, Clarendon, Oxford, 1991, p. 174.

(b) Bianchi, A.; Bowman-James, K.; García-España, E. Supramolecular Chemistry of Anions, Wiley-VCH, New York, 1997.

(c) Vazquez, M.; Fabrizzi, L.; Taglietti, A.; Pedrido, R. M.; Gonzalez-Noya, A. M.; Bermejo, M. R. Angew. Chem., Int. Ed. 2004, 43, 1962.

[2] (a) Silva, J.-J R. F. D.; Williams, R. J. P. The Biological Chemistry of the Elements: the Inorganic Chemistry of Life, Oxford University Press, Oxford, 2001, p. 315.

(b) Vallee, B. L.; Auld, D. S. Acc. Chem. Res. 1993, 26, 543

(c) Bush, I.; Pettingell, W. H.; Multhaup, G.; Paradis, M. D.; Vonsattel, J. P.; Gusella, J. F.; Beyreuther, K.; Masters, C. L.; Tanzi, R. E. Science 1994, 265, 1464.

(d) Fraker, P. J.; King, L. E. Annu. Rev. Nutr. 2004, 24, 277.

(e) Cuajungco, M. P.; Lees, G. J. Neurobiol. Dis. 1997, 4, 137.

(f) Frassinetti, S.; Bronzetti, G. L.; Caltavuturo, L.; Cini, M. Della Croce, C. J. Environ. Pathol. Toxicol. Oncol. 2006, 25, 597.

[3] (a) Lai, J.; Moxey, A.; Nowak, G.; Vashum, K.; Bailey, K.; McEvoy, M. J. Affective Disord. 2012, 136, 31.

(b) Weiss, J. H.; Sensi, S. L.; Koh, J. Y. Trends Pharmacol. Sci. 2000, 21, 395.

(c) Maes, M.; Vos, N. D.; Demedts, P.; Wauters, A.; Neels, H. J. Affective Disord. 1999, 56, 189.

[4] Carol, P.; Sreejith, S.; Ajayaghosh, A. Chem. Asian. J. 2007, $2,338$.

[5] (a) Zhang, J. F.; Bhuniya, S. Y.; Lee, H.; Bae, C.; Lee, J. H.; Kim, J. S. Tetrahedron Lett. 2010, 51, 3719.

(b) Voegelin, A.; Pfister, S.; Scheinost, A. C.; Marcus, M. A.; Kretzschmar, R. Environ. Sci. Technol. 2005, 39, 6616.

(c) Callender, E.; Rice, K. C. Environ. Sci. Technol. 2000, 34, 232.

(d) Li, L.; Dang, Y. Q.; Li, H. W.; Wang, B.; Wu, Y. Tetrahedron Lett. 2010, 51, 618.

[6] (a) Tang, L.; Zhou, P.; Zhong, K.; Hou, S. Sens. Actuators, B: 2013, $182,439$.

(b) Kumari, N.; Jha, S.; Bhattacharya, S. J. Org. Chem. 2011, 76, 8215 .

(c) Zhang, W.; Xu, K.; Yue, L.; Shao, Z.; Feng, Y.; Fang, M. Dyes Pigm. 2017, 137, 560 .

(d) Shan, Y.; Wu, Q.; Sun, N.; Sun, Y.; Cao, D.; Liu, Z. Macromol. Chem. Phys. 2017, 186, 295.

(e) Liu, T.; Huo, F.; Li, J.; Cheng, F.; Ying, C. Sens. Actuators, $B$ 2017, 239, 526.

[7] (a) Hachiya, H.; Ito, S.; Fushinuki, Y.; Masadome, T.; Asano, Y.; Imato, T. Talanta 1999, 48, 997.

(b) Wang, L. Y.; Li, L. Q.; Cao, D. R. Sens. Actuator, B 2017, 239, 1307.

(c) Kalpana, P.; Suganya, S.; Velmathi, S. Spectrochim. Acta, A 
2017, 171, 162.

(d) Li, H.; Zhao, P.; Zou, N.; Wang, H.; Sun, K. Tetrahedron Lett. 2017, 58,30 .

[8] Saenger, W. Principles of Nucleic Acid Structure, Springer, New York, 1988

[9] (a) Paredes, J. M.; Giron, M. D.; Ruedas-Rama, M. J.; Orte, A.; Crovetto, L.; Talavera, E. M.; Salto, R.; Alvarez-Pez, J. M. J. Phys. Chem. B 2013, 117, 8143 .

(b) Bhaumik, C.; Das, S.; Maity, D.; Baitalik, S. Dalton Trans. 2011, 40, 11795.

[10] (a) Irie, M. Chem. Rev. 2000, 100, 1685.

(b) Tian, H.; Yang, S. Chem. Soc. Rev. 2004, 35, 85.

(c) Irie, M.; Fukaminato, T.; Sasaki, T. Nature 2002, 420, 759.

(d) Fu, Y. L.; Fan, C. B.; Liu, G.; Pu, S. Z. Sens. Actuators, B 2017, 239, 295.

(e) Zhang, X.-X.; Wang, R. J.; Fan, C. B.; Liu, G.; Pu, S. Z. Dyes Pigm. 2017, 139, 208.

[11] (a) Wang, R. J.; Wang, N. S.; Pu, S. Z.; Zhang, X.-X.; Liu, G.; Dai, Y. F. Dyes Pigm. 2017, 146, 445.

(b) Wang, R. J.; Wang, N. S.; Tu, Y.-Y.; Liu, G.; Pu, S. Z. J. Photochem. Photobiol. A 2018, 364, 32. (c) Wang, R. J.; Diao, L.; Ren, Q. W.; Liu, G.; Pu, S. Z. ACS Omega 2019, 4, 309 .

[12] Irie, M.; Fukaminato, T.; Matsuda, K.; Kobatake, S. Chem. Rev. 2014, 114, 12174.

[13] Wu, J. S.; Liu, W. M.; Zhuang, X. Q. Org. Lett. 2007, 9, 33.

[14] Wang, H.; Wang, B.; Shi, Z. Biosens. Bioelectron. 2015, 65, 91.

[15] (a) Dong, W. K.; Li, X. L.; Wang, L.; Zhang, Y.; Ding, Y. J. Sens. Actuators, B 2016, 229, 370.

(b) Feng, E. T.; Tu, Y.-Y.; Fan, C. B.; Liu, G.; Pu, S. Z. RSC Adv. 2017, 7, 50188.

[16] Yao, K.; Fu, J. X.; Chang, Y. X.; Li, B.; Yang, L.; Xu, K. X. Spectrochim. Acta, Part A 2018, 205, 410.

[17] Sabyasachi, T.; Sudipta, D.; Milan, G.; Mahuya, B.; Kumar, H. S.; Pratim, M. P.; Debasis, D. Spectrochim. Acta, Part A 2019, 209, 170.

[18] Purkait, R.; Chattopadhyay, D. A.; Sinha, C. Spectrochim. Acta, Part A 2019, 207, 164.

[19] Karar, M.; Paul, S.; Biswas, B. Dalton. Trans. 2018, 276, 560.

[20] Cui, S. Q.; Pu, S. Z.; Liu, G. Spectrochim. Acta, Part A 2014, 132, 339.

(Li, L.; Fan, Y.) 